Article

\title{
A Theoretical Basis for Addressing Culture in Undergraduate Mining Education
}

\author{
Anne Johnson \\ Queens University, anne.johnson@queensu.ca
}

Competent navigation of cultural difference is critical to the management of social risk in the extractive sector as conflict associated with resource projects is often the consequence of a clash of cultures, as the extractive and growth values of Western, capitalist culture collide with the relational, stewardship values of indigenous cultures. Arguing that because most new mineral deposits are located on the traditional territories of indigenous peoples, intercultural competence should be a learning outcome of undergraduate mining education, a theoretical framework for a curriculum to support development of intercultural competence's skills and attitudes within the undergraduate engineering curriculum is presented.

\section{Introduction}

The term social license to operate, a measure of social risk, reflects the quality of companycommunity relationships in the extractive industries. Because most mining projects occur on the traditional territories of culturally distinct indigenous peoples, management of social risk requires that mining engineers build respectful relationships across the cultural divide.

Historically, mining education has not addressed culture, or included tools to engage with it, but as social risk increases (Owen and Kemp, 2013; Ernst and Young, 2018), failure to comprehend the cultural factors affecting industry-community trust, may explain the challenge of building relationships with affected communities.

\section{Culture}

Culture plays a role in conflict (Ting-Toomey, 1982; Avruch et al., 1991), including that associated with extractive projects (Kemp et al., 2010; Andrews et al., 2017). Because of culture's role in conflict, the study of culture must be included in the mining curriculum in order to understand the values that collide around extractive projects. Through an exploration of these collisions, development of relationship skills, and intercultural competence can be supported. 
Johnson, A

A Theoretical Basis for Addressing Culture in Undergraduate Mining Education

The encounter with cultural difference may be examined through a variety of theoretical lenses to provoke reflection upon the assumptions that hinder authentic and effective engagement between parties. Intersections and convergence of these lenses illustrate the potential for a curriculum which catalyzes a shift within engineering culture itself to increase graduate comfort with uncertainty and the unfamiliar.

We begin by describing how culture, and cultural change is understood in this work.

\section{Defining Culture}

Two definitions contribute to the way in which culture is conceptualized in this work. The first is ontological:

Culture provides the blueprint that determines the ways an individual thinks, feels, and behaves in society. We are not born with culture, but rather learn it through enculturation and socialization. It is manifested through societal institutions, lived experiences, and the individual's fulfillment of psychological and basic needs. (Gollnick \& Chinn, 2009, p.31).

Schein described culture in epistemological terms, referring to knowledge-a core of beliefs and assumptions that may be unconsciously held, but expressed as the values and outward patterns of behaviour that guide choices and actions:

... a pattern of shared basic assumptions that the group learned as it solved its problems of external adaptation and internal integration, that has worked well enough to be considered valid, and therefore, to be taught to new members as the correct way to perceive, think, and feel in relation to those problems. (Schein [in Godfrey \& Parker, 2010, p. 6]).

In essence, culture encompasses the worldview and production (epistemology axiology, artifacts and practices) of a group. In the anthropological tradition, culture refers to a kinship group: a tribal group with a common ancestry. The anthropological lens facilitates the study of constructed groups, such as employees of particular corporations and self-forming groups, such as the epistemic cultures of disciplinary and professional communities (Knorr-Cetina, 2001).

The term settler culture, referring to those who arrived in North America after Indigenous peoples, is a hybrid of kinship and self-forming groups. It functions as a placeholder in decolonizing literature by invoking the binary of otherness (Spivak [in Silverman, 1993]), to comprise the entirety of worldviews that fall outside Indigenous cultural norms.

The professions, as well as the corporations that employ them, are also theorized to have distinct cultures (Wilensky, 1964; Moore, 1970). Wenger posits that communities of practice, composed of those who share skills and type of work (e.g., the professions) also share assumptions and values (1999). Wenger's model is frequently referenced in engineering education, where young people work collaboratively to adopt the norms of a profession and build their identities as engineers. 
Johnson, A

A Theoretical Basis for Addressing Culture in Undergraduate Mining Education

\section{Cultural Change}

Martin (1992) describes three models of culture and associated paradigms to conceptualize change over time. These are evident in work on cultural change, particularly in the context of corporate culture (Deal \& Kennedy, 2000). These paradigms align with anthropological theory that cultural change is driven by:

- Environmental change

- Technological development

- New ideas resulting from

- Diffusion, or

- Acculturation

Because these occur over time, the shifts they trigger are theorized to also evolve gradually (Boyd \& Richerson, 1995). However, following Kuhn's 1970 introduction of the paradigm shift to model the evolution of scientific theory and Eldridge and Gould's 1972 work on punctuated equilibrium in evolutionary biology, cultural change has been explained in similar terms (Durham, 1990; Gersick, 1991).

Weick and Quinn (1999) argue that cultural change occurs as a consequence of singular dramatic events that destabilize a system (such as a culture) to the extent that its equilibrium point is altered. Gladwell borrowed the term tipping point, from epidemiology (2000) to refer to the destabilizing events occurring at thresholds of cultural shift.

Organizational culture, too, is theorized to be malleable. Leaders are advised to create or influence the "corporate culture," which is defined as the rules, values, and norms that govern behaviour within a workplace (Burack, 1991; Hofstede, 1997). The successful leader continually shapes culture to better achieve the organization's goals (Atkinson, 1990).

\section{The Culture of Engineering}

A call for cultural change in engineering education (Institute of Engineers Australia, 1996; Godfrey \& Parker, 2010; Mills et al., 2010), is persistent, but lack of agreement on changes sought and the role of curriculum supporting change are obstacles (Godfrey, 2003; Merton, et al., 2004).

\section{Engineering's Cultural Values}

Engineering students are known generally to be believers in the values of "economic growth" and technological progress (Johnson, 2016; Riley, 2008), ${ }^{1}$ as well as being concerned about issues related to sustainability (Johnson, 2016; Carew \& Mitchell, 2002) — more so than their (older) practicing colleagues (Brown, 2012).

Among the values that have been associated with engineering culture are: reliability, economy, safety, the potential of technology to solve the most complex problems, progress and innovation, curiosity and adventure, teamwork, competitiveness, hard work (Tonso, 2006; Heywood, 2005;

\footnotetext{
${ }^{1}$ Riley identified these attributes in American undergraduate engineers in 2008. To my knowledge, students of mining engineering have not been studied as a specific group.
} 
Johnson, A

A Theoretical Basis for Addressing Culture in Undergraduate Mining Education

Lucena et al., 2010), as well as, "a pleasure in technology," and "pride in technical competence" (Faulkner, 2000, p. 109). Dunne observes that engineers dislike uncertainty and are uncomfortable when they cannot control the behaviour of components in a system. He suggests that this discomfort, combined with the unpredictability of people, may be at the root of the presumption that engineers prefer machines to people (2005). Significantly, for future mining engineers, these discomforts are also characteristic of encounters with cultural difference.

\section{Epistemic Foundations of Engineering Culture}

A culture's worldview has its most appreciable and normative expression in its epistemology-not just its knowledge, but its beliefs about knowledge and the criteria it uses to validate or determine what counts as knowledge. Because a clash of epistemologies is often present in real-world conflict, a critical comparison of epistemologies has practical value in informing the design of complex systems where diverse cultures are brought together, as they often are in extractive projects.

Perry modeled the interaction between the cognitive and affective domains to scaffold learning over the entire course of college education (1970, [in King \& Magun-Jackson). Exploring shifts in students' beliefs about knowledge resulting from their learning experiences, Perry mapped epistemology across four dimensions to show how these shifts might, in turn, alter cognitive processes:

- Dualism: knowledge is based on a single answer provided by an authority

- Multiplicity: knowledge is based on differing opinions,

- Relativism: knowledge is dependent on a given scenario, and

- Commitment: knowledge is based on known information.

Perry found that engineering students scored lower than other students on the dualism and multiplicity dimensions. Later studies confirm Perry's findings: for example, engineering students are more likely than others to believe that knowledge is certain (Jehng [in King \& Magun-Jackson, 2009]), a belief that is problematic for meaningful encounters with cultural difference.

The Schommer Framework, conceives of epistemology as having four 2-part dimensions, as shown in Figure 1. Together, they represent individual relationships to knowledge (King \& Magun-Jackson, 2009). 
Johnson, A

A Theoretical Basis for Addressing Culture in Undergraduate Mining Education

\begin{tabular}{|l|l|l|}
\hline \multirow{2}{*}{ Dimension } & \multicolumn{2}{c|}{ Description of Beliefs } \\
\cline { 2 - 3 } & \multicolumn{1}{|c|}{ Naïve } & \multicolumn{1}{c|}{ Sophisticated } \\
\hline Structure & $\begin{array}{l}\text { Knowledge is simple, } \\
\text { consisting of isolated pieces } \\
\text { of information that are clearly } \\
\text { understood. }\end{array}$ & $\begin{array}{l}\text { Knowledge is complex, } \\
\text { consisting of pieces of } \\
\text { information that are related } \\
\text { and dependent on the other. }\end{array}$ \\
\hline Certainty & $\begin{array}{l}\text { Knowledge is certain, } \\
\text { absolute, and not changing. }\end{array}$ & $\begin{array}{l}\text { Knowledge is continuously } \\
\text { evolving }\end{array}$ \\
\hline Control & $\begin{array}{l}\text { Knowledge is innate and set } \\
\text { or fixed. }\end{array}$ & $\begin{array}{l}\text { Knowledge is incremental } \\
\text { and can increase or improve }\end{array}$ \\
\hline Speed & $\begin{array}{l}\text { Knowledge is quickly } \\
\text { obtained. }\end{array}$ & $\begin{array}{l}\text { Knowledge is obtained by a } \\
\text { gradual process. }\end{array}$ \\
\hline
\end{tabular}

Figure 1: The Schommer Framework

Schommer contends that beliefs about knowledge need not mature simultaneously. i.e. that beliefs in one dimension may be sophisticated, while those in another are naïve. For example, the Structure of knowledge dimension ranges from naïve to sophisticated. Similarly, the movement along Schommer's Certainty dimension begins with a belief that knowledge is certain, absolute, and immutable. With increasing intellectual development, students become less rigid in their conception of what counts as knowledge, and more cognizant of the fact that knowledge is expanding and subject to change, as both Dewey (1933) and Russell (2014) theorized.

This epistemological framework is consistent with transformative learning theory's position that learning in the cognitive domain can initiate changes in the affective domain, and that affective changes may be incremental and latent rather than immediate (Cranton, 2006).

\section{Confronting Culture: The Theoretical Basis}

Costa and Scoble (2006) argue that mining educators must produce "... global citizens who are politically, culturally, and socially aware," to show recognition of, "increasingly more diverse and complex responsibilities" (Scoble \& Laurence, 2008), and to answer calls from industry that training goes "beyond learning the hard sciences directly related to engineering to encompass the soft areas related to people, ethics in society, and the environment reflecting the complexity of the environment in which .decisions now have to be made." Hagan et al. want young engineers to be "able to work and communicate effectively across discipline boundaries" (2012). For mining engineers, these abilities need to extend across cultural boundaries, too.

The research on engineering education has not yet addressed "culture," or acquisition of skills associated with intercultural competence, although Costa and Scoble (2006, p. 8) state that, "The intention is to respond to current challenges, such as community participation in mining, sustainable development, capacity building, environmental impacts, risk communication, the concerns of Aboriginal peoples, land access, conflict and poverty alleviation, among others" ( $p$ 371).

The curriculum developed to address these questions was informed by the theories of transformative learning and situated learning, as well as critical theories, which interrogate implicit societal assumptions. 
Johnson, A

A Theoretical Basis for Addressing Culture in Undergraduate Mining Education

\section{Adult Learning Theories}

Because almost all of the tracked learning outcomes for Canadian engineering graduates reside in the cognitive domain (Engineers Canada, 2016), it is challenging to determine where in the curriculum, development of intercultural competence and dialogic skills might be included. The few outcomes specified in Canada's accreditation criteria which do reside in the affective domain - the learning that involves feelings and values - relate to teamwork and professional ethics: nowhere are issues of equity and empathy addressed (Engineers Canada, 2016).

\section{Transformative Learning}

Mezirow's theory of transformative learning provides a model for understanding how learning in the cognitive and affective domain relate, and how educators can support affective learning outcomes via learning in the cognitive domain. Mezirow states that, "Most of the process of learning occurs outside of awareness and may include emotional, intuitive, symbolic, imaginistic, and/or contemplative modes of learning" (Dirkx et al., 2006, p.124). Thus, for the purpose of assessment, the affective domain and its processes are troublesome. Mezirow contends however, that even though processes of transformative learning occur outside of the learner' awareness, learning can be accessed and consolidated if it is brought into the learner's awareness through reflection. He lists elements of awareness that are indicative of reflection upon epistemic assumptions and amenable to observation:

1. recognition that an alternative way of understanding may provide new insights into a problem;

2. context awareness of the sources, nature, and consequences of an established belief;

3. critical reflection of the established belief's supporting epistemic assumptions;

4. validating a new belief by

a. an empirical test of the truth of its claims, when feasible, or

b. a broad-based, continuing, discursive assessment of its justification to arrive at a tentative best judgment;

5. anxiety over the consequences of taking transformative action; and

6. taking reflective action ${ }^{2}$ on the validated belief (Dirkx et al., 2006, p 124).

Importantly, for mining education, while the objectives of transformative learning reside in the affective domain, the route to desired affective outcomes need not be limited to learning activities that would be recognized as engaging the affective domain —indeed, Cranton (2006) presents a number of examples in which adult learners experienced a life-changing transformation as a consequence of learning in what might have been thought to be unremarkable, even "objective," subject areas. Dirkx observes that even though transformative impacts occur in the affective domain, the process necessarily involves a cognitive or rational process, in which a learner

\footnotetext{
${ }^{2}$ The learner elects to take different actions than he/she would have before the transformation. Reflective action means that the learner is aware that his/her knowledge has expanded and that this has led to a re-evaluation of assumptions and their influence. Taking reflective action is the final step in transformative learning, in which the learner intentionally acts according to transformed beliefs and values. Dewey (1933) said that reflective action requires "... .active, persistent, and careful consideration of any belief or supposed form of knowledge in the light of the grounds that support it and the further conclusions to which it leads" (p. 9).
} 
Johnson, A

A Theoretical Basis for Addressing Culture in Undergraduate Mining Education

critically assesses her own epistemic assumptions, as their limitations come into awareness (2006). Thus, transformative learning is fundamentally a cognitive process not facilitated by aspirations or motivations alone (Dirkx et al. 2006, p. 133).

Belenky and Stanton (2000) conceive of transformative learning as a discursive process, an internal dialogue through which the learner develops capacity for reflection and critical thinking about unquestioned assumptions that have girded her relationship to the world. Mining's diverse contexts offer innumerable opportunities for such reflection.

Mezirow advises that the contexts where promoting transformative learning is most appropriate are those where problems involve reasoning about complex and highly contextual collections of information (2000). Problems such as those in mining provide opportunities to study cases illustrating the ways in culturally determined worldviews or frames of reference lead to divergent attitudes. Facilitation of critical engagement can lead students deeper into to epistemic reflection and adoption of the inclusive and accepting frames of reference, which are also indicators of intercultural competence.

A curriculum designed to support the student understanding of culture will not be straightforward to evaluate: achievement of learning outcomes related to expectations and metrics for social responsibility and some aspects of culture can be assessed directly, but determining whether transformative learning has resulted is difficult because of latency and a limited assessment window.

\section{Situated Learning}

Eraut states, "Professional knowledge cannot be characterized in a manner that is independent of how it is learned and how it is used" (1994, p. 19). Situated learning theory holds that learning occurs when learners construct new, increasingly sophisticated models of reality, in response to observations and experience of the world.

For most professions, learning outcomes are prescribed by an accrediting body. While individual schools and instructors may enrich the learning experience, the defining outcome of all professional education is the production of a "professional" - here, a mining engineer.

A significant part of professional training includes socialization into the professioninternalization of its cultural norms, ideologies and practices (Trice,1993; Dryburgh, 1999). Indeed, some argue that it is the development of an "identity" that characterizes successful engineering education (Walker, 2001; Stevens et al., 2008).

Situated learning theory models the process of socialization into a profession. It holds that learning is situated in communities of practice: social groupings held together, formally or loosely around an enterprise - an activity engaged in by group members - rather than a mere interest (Lave \& Wenger, 1991). Such enterprises may reside in realms of recreation (clubs) or occupation (professions). Significantly, the communities of practice model views learning as an integrated cognitive-social process involving acquisition of skill and coming to identify with the group: acquiring a new cultural identity.

The education of mining engineers, can thus be seen as both a social and cognitive process. Lave and Wenger describe the process of enculturation into a profession through "authentic activity"the use of professional tools in context, and they acknowledge the powerful influence of a profession's cultural norms on its novices. 
Johnson, A

A Theoretical Basis for Addressing Culture in Undergraduate Mining Education

The training of young engineers has traditionally been about "becoming an engineer," as much as about acquiring the skills and knowledge required for practice (Tonso, 1996). Accordingly, critical engagement with cultural difference must be constructed within the norms of the profession, if training is to support a transformative learning experience that results in an engineer who is also culturally competent.

\section{Critical Theories}

Critical theories deconstruct the mechanisms by which the dominant elements in a society consolidate and maintain power. Educators can employ critical methodologies within the curriculum to enable students to recognize sources of oppression that contribute to social risk around mining projects. Critique infuses the disciplines of development and political studies, which examine mining impacts, but it is not a feature of mining education in Canada (CIM Mining Education Forum, Montreal, May 1, 2019).

\section{Decolonization}

Mining related conflict often occurs at sites with a history of colonization (Andrews et al., 2017). Decolonization theory examines the legacies of the colonial project and their effects upon peoples within nations that have a colonial past. It interrogates mechanisms by which cultural imperialism was (and continues to be) effected, as well as ways in which these mechanisms influence both colonized and colonizer.

Decolonization is an activist critical theory that seeks to "undo" colonization by re-establishing the legitimacy of Indigenous epistemologies through the interrogation of settler colonialism.

Battiste (2004) argues that the disciplinary knowledge expressed in the discourse of the professions institutionalizes hegemony of the colonizing culture. Speaking specifically of scientific knowledge, Harding (1992) and Luke (2005) explore the implications of imperialism on approaches to environmental knowledge. Decolonization theory argues that the education system is instrumental in privileging the worldview of the dominant group in a society-in Canada, that of the settler - including empiricism, individualism, and capitalism, and seeks to democratize disciplinary discourse via inclusion of broader epistemic perspectives (Canagarajah, 1999). Because dominance of the western epistemological paradigm relies on the avoidance of questioning the criteria by which knowledge is validated, specifically: empiricism, objectivity, and universality, confronting culture is imperative for decolonizing theory.

Decolonization is hostile to established conception of a robust extractive sector and to industry itself. It reveals that resistance to mining is not growing within a vacuum of ignorance or misunderstanding of industry, but rather, at least in part, because of a determined and compelling philosophy that is growing in influence, fueled by feelings of frustration felt by the cultural communities who continue to be oppressed in the post-colonial era, and by an awakening to global issues of social justice within academia. Within mining education, the role for the decolonizing lens can provide further insight into the chasm between worldviews that interact when a mine is proposed, and to how curriculum is presented.

While the political and social injustice felt by non-dominant groups in a larger society is recognized, there is as yet insufficient comprehension of the ethical implications of failing to recognize their knowledge, and in particular, the role of this failure in both conflict and the reinforcement of systemic injustices. 
Johnson, A

A Theoretical Basis for Addressing Culture in Undergraduate Mining Education

\section{Power Knowledge}

Foucault's Power-Knowledge theory unites Decolonizing theory with Transformative and Situated Learning theories to reveal an approach for educating young mining engineers. Foucault argued that perspective, rather than truth, determines what constitutes knowledge, while power determines whose perspective is legitimate. He observed that power is subtly reinforced through control of discourse (1980). Foucault's conceptualization of the interplay between power and knowledge offers an alternative way to understand the relationships among stakeholders in extractive sector projects. It is also key to re-imagining a role for the socially and culturally competent mining engineer.

Foucault's conclusions regarding the linkage between power and knowledge relied upon an initial rejection of the way in which language had been conceived. To capture previously overlooked qualities embedded within language, Foucault borrowed the term discourse from linguistics, redefining it as a combination of vocabulary, syntax, semantics, class/cultural norms, and etiquette, a single meta-concept.

Foucault concluded that power rests in the coercive and normative force of representation through discourse. Discourse is the heart of power: through it and in it, the epistemology and objectives of the dominant culture become embedded and reinforced. Discourse is thus at the heart of inequality, because cultural control of the discourse is both an exercise of power as well as an expression of power. Through discourse, knowledge and values are controlled, and for Foucault, controlling the worldview is the most potent source of power. This concern is echoed in Mezirow's charge that post-secondary education can be mere instrumental learning in which "...cultural canon, socioeconomic structures, ideologies, and beliefs about self often conspire to foster conformity and impede development of a sense of responsible agency" $(2000$, p. 8).

Lave and Wenger contend that the period of education imposes both external (desire for group belonging) and internal (desire to possess an identity) pressure upon the student to engage in professional discourse through the acquisition of disciplinary knowledge and adoption of disciplinary values - the power that is embodied in this knowledge is thereby both communicated and reinforced (1991). Reid and $\mathrm{Ng}$ (1999) explain the relationship between language and power in greater detail: as well as reflecting and creating power, language depoliticizes and "routinizes" power (p. 121). The language of dominance, they argue, reinforces the relationship of dominance, making inequality seem natural, beyond question, and thus, the fact that the language of science is laden with cultural values is difficult for members of the dominant group to comprehend.

Industry's discourse respecting sustainable development, might be explored within the mining curriculum to reveal assumptions that permit the dominant culture to overlook the concerns of affected (culturally distinct) communities, in order to model a critical, culturally-aware approach to the practice of engineering.

Traditional knowledge theories, relate more closely to Foucault's Power-Knowledge than to Decolonizing theory in that they deal with discourse, challenging the primacy of western scientific knowledge (Iaccarino, 2003) and suggesting that the relational and non-linear worldview expressed in traditional knowledge systems, such as those preserved within many Indigenous oral traditions, are equally valid and possess equivalent capacity for representing what can be known about a place. Berkes et al. (2000) warn that it should not be assumed that such knowledge is held exclusively by peoples who are recognized as "indigenous," but should be 
Johnson, A

A Theoretical Basis for Addressing Culture in Undergraduate Mining Education

understood to refer to knowledge about the symbiotic relationships of organisms in a particular place, which is preserved and passed from generation to generation through the oral tradition. Such holistic theories compliment Foucault's Power-Knowledge by their argument that the positivist knowledge tradition is not superior, but, as Nakashima and Roué describe, differently constructed (as cited in Mazzocchi, 2006). Local ecological knowledge theorists argue that place-based unique and precious knowledge is the inalienable cultural heritage of land-based peoples, for whom such knowledge forms part of their cultural identity and integrity (Mazzocchi, 2006).

\section{Dialogue Theories}

A number of classification systems characterize communication styles, and their assumptions (Morsing \& Schulz, 2006; Krauss \& Morrcella, 2006; Tufte \& Mefalopulos, 2009). All contrast traditional transmission or monologic paradigms and those that are dialogic, or participatory. In recent years, the inadequacies of monologic approaches have become apparent, especially for communication of environmental risk (Fiorino, 1990; Tufte \& Mefalopulos, 2009), yet truly dialogic models have not been adopted, notwithstanding the embrace of "stakeholder engagement" in business (Morsing \& Schultz, 2006).

Conflict around extractive projects often begins with communication failure and the likelihood of failure increases with cultural difference (Triandis, 2000; Andrews et al., 2017; Perrson et al., 2017). Since communication styles and language systems are both cultural products and the means by which culture is transmitted, it is worthwhile considering the role of communication in negotiating cultural distance.

Beginning with a powerful analogy that emerges from a process that can be instinctively grasped, Dialogue Theory, or Dialogism, offers a non-threatening framework for conceptualizing relationships between not only individuals, but cultures. Although they are concerned with different characteristics and applications, the major philosophers of dialogue (Bakhtin, 1981; Buber, 1970) share the conviction that dialogue's defining quality is connection, or relationship.

As Mazzocchi notes, "Dialogue can become a tool for social cohabitation, as well as for discovering and enhancing knowledge" (2006, p. 466). Specifically, dialogue theory provides a tool for conceptualizing a knowledge state in which incompatible or contradictory conceptions are held to be true simultaneously. As the process of dialogue unfolds, these conceptions evolve: influencing each other by turns, creating distinct new understandings which comprise layers of meaning, perhaps a merged and comprehensive understanding, or perhaps a transformed and entirely unrecognizable understanding.

Bakhtin's dialogic model (1981) supports the development of a non-reductionist and inclusive view of diverse knowledges that will be useful for the culturally competent engineer. Because it avoids de-valuing Western scientific views of knowledge during the critical formative period of engineering education, in which students adopt the culture of the profession, Bakhtin's dialogism lends itself to the construction of a flexible knowledge framework that has the capacity to accommodate the evolving understanding of perspectives, which is needed to conceptualize and incorporate cultural constraints (e.g. those related to stakeholders) in engineering practice.

Dialogism provides the theoretical foundation for considering competing worldviews in a manner conducive to the building of respect, trust, and relationships. If young engineers are to be prepared to be culturally aware and effective communicators in the field, their training must 
Johnson, A

A Theoretical Basis for Addressing Culture in Undergraduate Mining Education

enable them to concurrently internalize disciplinary knowledge and acknowledge that all knowledge is a function of epistemological viewpoint.

Bakhtin conceives of dialogue as both process and perspective - a space created for conceptions that have no correspondence across cultures, so that, as meaning is collaboratively made and remade in a dialectic exchange, mutual understanding (or, as Bakhtin would contend, truth) emerges. Dialogism allows for acceptance of the simultaneous legitimacy of opposing views, suggesting that it is a truth that eventually emerges. Furthermore, dialogism can be taken a step further beyond simply allowing opposing views, to enable the modeling of mutually exclusive knowledges, and leading to a resolution through the dialogical process, i.e. a shared understanding of culturally contentious concepts.

Bakhtin's notion that truth is a composite of many truths is useful for interrogating the privileging of scientific over other forms of knowledge (such as traditional knowledge) and offers a framework for mediating between perspectives. It may be possible to employ this framework for responding to challenges to a worldview in a way that is non-threatening but which may still be a catalyst for transformation. Dialogism posits that various contradictory positions can be all be true and that a more comprehensive truth requires that these be assimilated into a new, nuanced and complete truth.

Dialogism offers a constructive, collaborative approach to negotiating difference. Significantly, Buber noted that dialogue is possible even where participants hold unequal power, but if authentic dialogue occurs, the outcome will necessarily be a transformed relationship of equals (2003). In Buber's view, dialogue's authenticity is a function not of speaking or being heard, but of the intention to understand the other and his/her experience (2003). Put another way, the ontological space between beings may be treated as distance - an impediment to relationship, or it may be treated as opportunity for relationship. Through dialogue comes respect and with relationship, the opportunity for partnership.

\section{Cross Cultural Communication Theories}

The term global competence has been proposed to capture the skills essential to twenty first century engineers (Lohmann, et al., 2006; Parkinson, 2009). Downey et al. (2006), describe global competence as the measure of an engineer's ability to work with colleagues who "define problems differently," a measure that is inadequate to capture the requirement for mining engineers to work with stakeholders, who may not share team goals or who may oppose them altogether. Several communication models theorize the intercultural encounter.

Cultural Intelligence (CQ) explains the phenomena of a) individuals functioning at high levels of competence within their own cultural milieu yet failing to function in other cultures, and b) success in unfamiliar cultural setting by individuals who are less socially skilled in their own cultural context (Earley \& Ang, 2003). However, CQ is preoccupied with results-driven strategy, rendering this model antithetical to the goals of trust and relationship- building. In seeking to support achievement of unilaterally determined goals (i.e. by the party belonging to the dominant culture) in intercultural contexts, CQ is fundamentally hegemonic and mono-cultural.

\section{Intercultural Competence}

The Developmental Model of Intercultural Sensitivity (DMIS) proposes a set of skills and attitudes that enable effective engagement with cultural difference-intercultural competence 
Johnson, A

A Theoretical Basis for Addressing Culture in Undergraduate Mining Education

(Bennett, 1993). Attitudes that correlate with intercultural competence are observable in behaviours including:

- awareness that all perspectives are functions of culture

- respect for diversity

- appreciation of difference

- comfort within one's own culture

- $\quad$ self-reflection, and

- avoidance of the rush to judge motivations behind observed behaviours.

Intercultural competence requires skills that enable the appreciation and negotiation of difference through dialogic processes As shown in Figure 2, the DMIS theorizes developmental stages of intercultural competence, which mark increasing capacity for interacting effectively with difference.

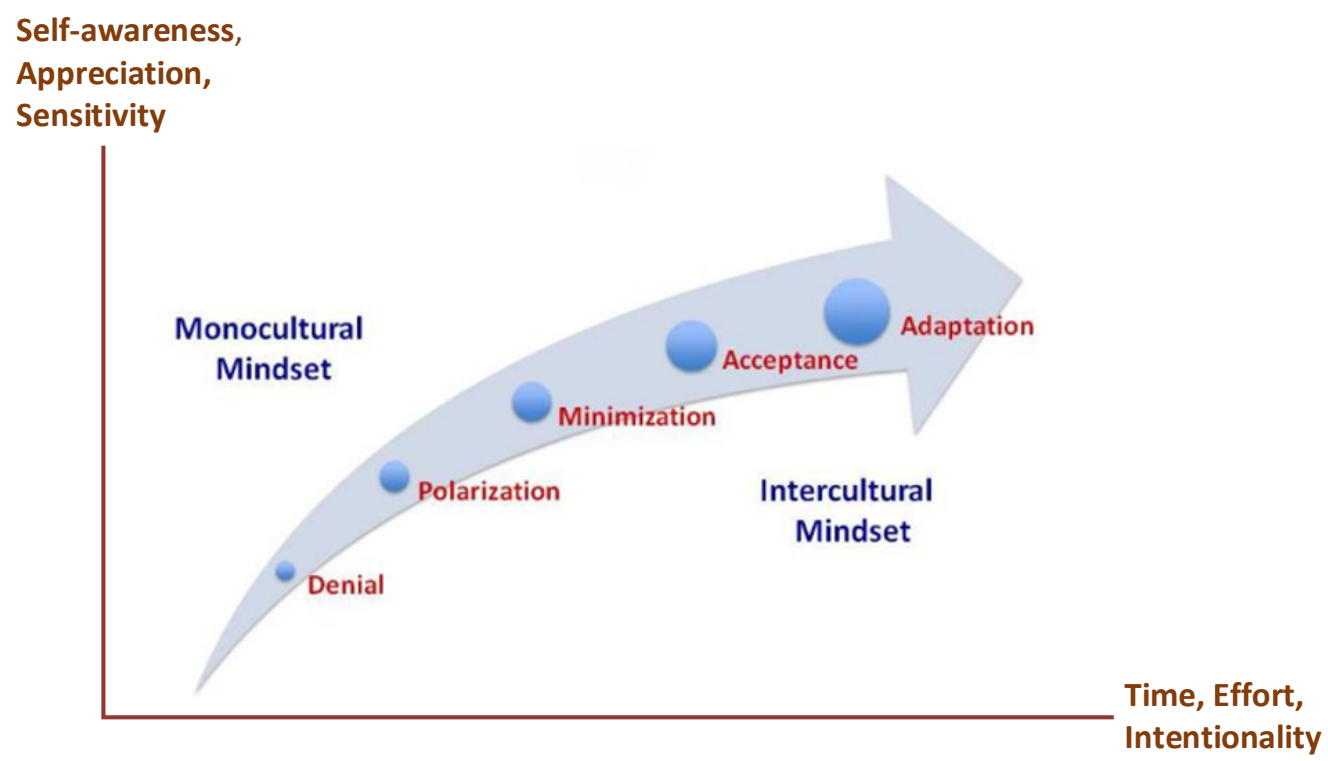

Figure 2: The Developmental Stages of Intercultural Competence (adapted from Hammer, 2012)

Stages of development progress through:

- Denial: lack of awareness or denial of difference.

- Polarization: a problematized view of the world as "us" and "them."

- Minimization: willingness but attendant only to superficial commonalities and shared values, and failure to appreciate deeper values.

- Acceptance: recognition of patterns of cultural difference as well as shared values.

- Adaptation: ability to shift one's own perspective and adapt behaviours in ways that are culturally appropriate but authentic (Hammer, 2012). 
Johnson, A

A Theoretical Basis for Addressing Culture in Undergraduate Mining Education

Although the DMIS does not confront the issue of asymmetric power between cultures, found in settler- or post-colonial contexts, it models development of intercultural competence, which is the objective for addressing culture within the mining curriculum.

The failure to confront power dynamics in intercultural encounters in the mining context requires the consistent application of critical theories to mining education, providing lenses through which social phenomena can be examined. Their application has potential to reveal to engineering students gaps in their worldview sufficient to initiate critical reflection upon modes of thinking that have become dysfunctional.

\section{Challenges}

Relationships between mining and communities must become more equitable — rebalancing the encounter with cultural difference, shifting towards epistemic openness through undergraduate mining education will help. Yet, even with a robust theoretical framework to inform the design of a curriculum that will support the development of knowledge, insight and skills associated with intercultural competence, there are impediments. Significant among the many obstacles, are a crowded curriculum (Boyle, 1999; McDivitt, 2002), workload concerns (Clarke et al., 2004), institutional disincentives (Huntzinger et. al., 2007), perennial debate around "soft-skills" (Berggren et al., 2003), pressures to maintain program consistency (Godfrey, 2003), in addition to lukewarm institutional support.

Yet, Canada's commitment to Reconciliation with Indigenous peoples calls upon every sector to contribute. Speaking of the role of universities to support Reconciliation, David Barnard writes:

We begin to decolonize our universities by integrating indigenous knowledge, perspectives and worldviews into curricula, programs and services, and providing relevant training for those teaching and interacting with our students. When understanding of First Nation, Métis and other indigenous cultures is woven through all of our campuses, then real change will occur not only within the institution, but within the many areas of society that we reach (2015).

Challenges notwithstanding, for mining education, it is time. 
Johnson, A

A Theoretical Basis for Addressing Culture in Undergraduate Mining Education

\section{References}

Andrews, A., Elizalde, B., LeBillon, P., Oh, C., Reyes, D., \& Thomson, I. (2017). The Rise in Conflict Associated with Mining Operations: What Lies Beneath. Canadian International Resources and Development Institute. https://cirdi.ca/wpcontent/uploads/2017/06/Conflict-Full-Layout-060817.pdf

Atkinson, P. (1990). Creating Culture Change. London: IFS.

Avruch, K., Black, P. W., \& Scimecca, J. A. (Eds.). (1991). Conflict resolution: Cross-cultural Perspectives, (No. 28). Westport, CT: Greenwood Press.

Bakhtin, M. (1981). The Dialogic Imagination: Four Essays by MM Bakhtin (M. Holquist, Ed.). New York: Dover.

Barnard, D. (2015). The role of Canada's universities in reconciliation. Universities Canada.

Battiste, M. (2004). Unfolding the lessons of colonization, in C. Sugars (Ed.) Unhomely States: Theorizing English-Canadian Postcolonialism, (pp. 209-220). Peterborough, ON: Broadview.

Belenky, M. \& Stanton, A. (2000). Inequality, development, and connected knowing, in J. Mezirow (Ed.), Learning as Transformation: Critical Perspectives on a Theory in Progress (pp. 71-102). San Francisco: Jossey-Bass.

Bennett, M. (1993). Towards a developmental model of intercultural sensitivity, in R. M. Paige, (Ed.) Education for the Intercultural Experience. Yarmouth, ME: Intercultural Press, 1993.

Berggren, K-F., Brodeur, D., Crawley, E., Ingemarsson, I., Litant, W., Malmqvist, J. \& Östlund, S. (2003). CDIO: an international initiative for reforming engineering education. World Transactions on Engineering and Technology Education. 2 (1). Accessed Nov 24, 2015 at http://wvvw.cdio.org/files/document/file/cdio international.pdf

Berkes, F., Colding, J. \& Folke, C. (2000). Rediscovery of traditional ecological knowledge as adaptive management. Ecological Applications 10(5), 1251-1262. https://doi.org/10.1890/1051-0761(2000)010[1251:ROTEKA]2.0.CO;2

Boyd, R., \& Richerson, P. (1996). Why culture is common, but cultural evolution is rare. Proceedings of the British Academy 88, pp. 77-94. http://www.britac.ac.uk/pubs/proc/files/88p077.pdf

Boyle C. (1999). Education, sustainability, and cleaner production. Journal of Cleaner Production 7(1), 83-87. http://www.sciencedirect.com/science/article/pii/S0959652698000456

Brown, A. (2012) Penetrating the engineering culture: according to the latest ASME/Autodesk survey, more engineers than ever before are working on green projects. Is sustainability simply becoming part of what engineers do? Mechanical Engineering CIME 134:10, p 
Johnson, A

A Theoretical Basis for Addressing Culture in Undergraduate Mining Education

42. http://search.proquest.com/docview/1095775928?accountid=6180

Buber, M. (2003). Between Man and Man. London: Routledge Classics.

Burack, E. (1991). Changing the company culture-the role of human resource development. Long Range Planning, 24(1), 88-95. http://journals2.scholarsportal.info/pdf/00246301/v24i0001/88 ctccrohrd.xml

Canagarajah, S. (1999). Resisting Linguistic Imperialism in English Teaching. Oxford: Oxford University Press.

Carew, A., \& Mitchell, C. (2002). Characterizing undergraduate engineering students' understanding of sustainability. European journal of engineering education, 27(4), 349361. http://www.tandfonline.com/doi/pdf/10.1080/03043790210166657

Clark, C., Froyd, J., Merton, P. \& Richardson. J. (2004). The evolution of curricular change models within the Foundation Coalition. Journal of Engineering Education 93(1), 37-47. http://onlinelibrary.wiley.com/doi/10.1002/j.2168-9830.2004.tb00786.x/epdf

Costa, S., \& Scoble, M. (2006). An interdisciplinary approach to integrating sustainability into mining engineering education and research. Journal of Cleaner Production, 14(3), 366373.

http://citeseerx.ist.psu.edu/viewdoc/download?doi=10.1.1.110.9260\&rep=rep1\&type=pdf

Cranton, P. (2006). Understanding and Promoting Transformative Learning: A Guide for Educators of Adults. Jossey-Bass Higher and Adult Education Series. San Francisco: Jossey-Bass.

Deal, T. \& Kennedy, A. (2000). Corporate Cultures: The Rites and rituals of Corporate Life. Boston: Da Capo Press.

Dewey, J. (1933). How we think: A restatement of the relation of reflective thinking to the educative process (2nd Ed). Boston: Houghton-Mifflin.

Dirkx, J., Mezirow, J. \& Cranton, P. (2006). Musings and reflections on the meaning, context, and process of transformative learning: a dialogue between John M. Dirkx and Jack Mezirow. Journal of Transformative Education, 4(2), 123-139. https://doi.org/10.1177/1541344606287503

Downey, G., Lucena, J., Moskal, B., Parkhurst, R., Bigley, T., Hays, C., \& Lehr, J. (2006). The globally competent engineer: Working effectively with people who define problems differently. Journal of Engineering Education, 95(2), 107-122. http://onlinelibrary.wiley.com/doi/10.1002/j.2168-9830.2006.tb00883.x/epdf

Dryburgh, H. (1999). Work hard, play hard-women and professionalization in engineering adapting to the culture. Gender and Society 13(5), 664-682. http://gas.sagepub.com/content/13/5/664.short

Dunne, J. (2005). What's the good of education, in W. Carr (Ed.), The RoutledgeFalmer Reader in Philosophy of Education, (pp. 145-160). London: Routledge.

Durham, W. (1990). Advances in evolutionary culture theory. Annual Review of Anthropology 
Johnson, A

A Theoretical Basis for Addressing Culture in Undergraduate Mining Education

19: 187-210. http://www.jstor.org/stable/2155963?seq=1\#page scan tab contents

Earley, P., \& Ang, S. (2003). Cultural Intelligence: Individual Interactions Across Cultures. Stanford, CA: Stanford University Press.

Eldridge, N., \& Gould, S. (1972). Punctuated equilibria: an alternative to phyletic gradualism, in Models in Paleobiology. San Francisco: Freeman, Cooper.

Engineers Canada. (2014). Canadian Engineers for Tomorrow: Trends in Engineering Enrollment and Degrees Awarded 2009-2013. http://www.engineerscanada.ca/sites/default/files/enrolmentreport2013-en-3.pdf

Engineers Canada. (2016). Graduate Attributes. https://engineerscanada.ca/sites/default/files/Graduate-Attributes.pdf

Eraut, M. (1994). Developing Professional Knowledge and Competence. Washington: Falmer.8

Ernst and Young. (2018). Business Risks Facing Mining and Metals 2019-20: Does operating in a time of disruption take more than a license? https://assets.ey.com/content/dam/eysites/ey-com/en_gl/topics/mining-metals/mining-metals-pdfs/ey-top-10-business-risksfacing-mining-and-metals-in-2019-20_v2.pdf

Faulkner, W. (2000). The power and the pleasure? A research agenda for "making gender stick" to engineers. Science, Technology \& Human Values, 25(1), 87-119. http://sth.sagepub.com/content/25/1/87.full.pdf

Foucault, M. (1980). Power/Knowledge: Selected Interviews and Other Writings, 1972-1977. New York: Vintage.

Gersick, C. (1991). Revolutionary change theories: a multilevel exploration of the punctuated equilibrium paradigm. The Academy of Management Review, 16(1),10-36. http://www.jstor.org/stable/258605

Gladwell, M. (2006). The Tipping Point: How Little Things Can Make a Big Difference. New York: Little, Brown.

Godfrey, E. (2003). A theoretical model of the engineering education culture: A tool for change. Proceedings of 2003 Annual Conference and Exposition of the American Society for Engineering Education. Nashville, TN. https://peer.asee.org/a-theoreticalmodel-of-the-engineering-education-culture-a-tool-for-change

Godfrey, E., \& Parker, L. (2010). Mapping the cultural landscape in engineering education. zrnal of Engineering Education, 99(1), 5-22. http://onlinelibrary.wiley.com/doi/10.1002/j.2168-9830.2010.tb01038.x/epdf

Gollnick, D. \& Chinn, P. (2009). Multicultural Education in a Pluralistic Society (8th ed.). Upper Saddle River, NJ: Pearson Education.

Hagan, P., Beamish, B., \& Daly, C. (2012). A project management approach to the undergraduate mining engineering thesis. Cuprum (4), 27-36. https://www.researchgate.net/profile/Paul_Hagan3/publication/259972481_A_project_ma 
Johnson, A

A Theoretical Basis for Addressing Culture in Undergraduate Mining Education

nagement approach to the undergraduate_Mining_Engineering thesis/links/0deec52f08 4bedcab5000000.pdf

Hammer, M. (2012). The Intercultural Development Inventory: A new frontier in assessment and development of intercultural competence. In M. Vande Berg, R. Paige, \& K. Lou (Eds.), Student Learning Abroad (pp. 115-136). Sterling, VA: Stylus. https://idiinventory.com/wp-content/uploads/2013/08/HAMMER-STUDY-ABROADARTICLE-2012.pdf

Harding, S. (1992). After Eurocentrism: challenges for the philosophy of science. PSA:

Proceedings of the Biennial Meeting of the Philosophy of Science Association, 311-319. http://www.jstor.org/stable/pdf/192845.pdf?=1459970666570

Heywood, J. (2005). Engineering Education: Research and Development in Curriculum and Instruction. Hoboken: Wiley-Interscience.

Hofstede, G. (1997). Attitudes, values and organizational culture: disentangling the concepts. Organization Studies, 19(3), 477-492. http://oss.sagepub.com/content/19/3/477.full.pdf

Huntzinger, D., Hutchins, M. Gerke, J. \& Sutherland, J. (2007). Enabling sustainable thinking in undergraduate engineering education. The International Journal of Engineering Education 23 (2), 218-230.

https://pdfs.semanticscholar.org/8b7a/bd58ff71904c04baf981bd3efb1e8fa207e1.pdf

Iaccarino, M. (2003). Science and culture. EMBO reports, 4(3), 220-223.

http://embor.embopress.org/content/4/3/220.abstract

Institute of Engineers, Australia. (1996). Changing the Culture: Engineering Education into the Future: Task Force Reports / [Review of Engineering Education Steering Committee]. Sydney, NSW: IEAus.

Johnson, E. (2016). Mitigating Social Risk in the Extractive Sector: Developing Intercultural Competence as a Tool for Negotiating Western-Indigenous Perspectives within the Undergraduate Mining Engineering Curriculum. PhD Thesis. Kingston: Queen's University. https://qspace.library.queensu.ca/bitstream/handle/1974/14716/Johnson_Elizabeth\%20_A 201608 PHD.pdf? sequence $=$

Kemp, D., Bond, C. J., Franks, D. M., \& Cote, C. (2010). Mining, water and human rights: making the connection. Journal of Cleaner Production, 18(15), 1553-1562. https://doi.org/10.1016/j.jclepro.2010.06.008

King, B. \& Magun-Jackson, S. (2009). Epistemological beliefs of engineering students. Journal of Technology Studies 35(2), 56 - 64. http://scholar.lib.vt.edu/ejournals/JOTS/v35/v35n2/king.html

Knorr-Cetina, K. (2009). Epistemic Cultures: How the Sciences Make Knowledge. Boston: Harvard University Press. 
Johnson, A

A Theoretical Basis for Addressing Culture in Undergraduate Mining Education

Krauss, R., \& Morsella, E. (2006). Communication and conflict, in M. Deutch, P. Coleman \& E. Marcus (Eds.) The Handbook of Conflict Resolution: Theory and Practice. San Francisco: Jossey Bass. 131-143.

Kuhn, T. (1970). The Structure of Scientific Revolution (2e). (Chicago: University of Chicago Press.

Lave, J. \& Wenger, E. (1991). Situated Learning: Legitimate Peripheral Participation. Cambridge, MA: Cambridge University Press.

Lewis, S., Mclean, C., Copeland, J. \& Lintern, S. (1998). Further explorations of masculinity and the culture of engineering. Australasian Journal of Engineering Education 8(1), 59-78.

Lohmann, J., Rollins, H., \& Hoey, J. (2006). Defining, developing, and assessing global competence in engineers. European journal of engineering education, 31(1), 119-131. http://www.tandfonline.com/doi/pdf/10.1080/03043790500429906

Lucena, J., Schneider, J., \& Leydens, J. (2010). Engineering and Sustainable Community Development. Morgan \& Claypool.

Luke, T. (1995). On environmentality: geo-power and eco-knowledge in the discourses of contemporary environmentalism. Cultural Critique 31: Part 2 The Politics of Systems and Environments, 57-81. http://www.jstor.org/stable/pdf/1354445.pdf?_=1460142525562

Martin, J. (1992). Cultures in Organizations: Three Perspectives. Oxford: Oxford University Press.

Mazzocchi, F. (2006). Western science and traditional knowledge. European Molecular Biology Organization EMBO Reports 7(5), 463- 466. http://onlinelibrary.wiley.com/doi/10.1038/sj.embor.7400693/epdf

McDivitt, J. (2002). Status of education of mining industry professionals. Mining, Minerals and Sustainable Development, International Institute for Environment and Development, (38). http://pubs.iied.org/pdfs/G00953.pdf

Merton, P., Froyd, J., Clark, M., \& Richardson, J. (2004). Challenging the norm in engineering education: Understanding organizational culture and curricular change. In $C D$ ) Proceedings, 2004 ASEE Annual Conference. http://www.foundationcoalition.org/events/news/conferencepapers/2004asee/merton.pdf

Mezirow, J. (2000). Learning as Transformation. San Francisco, CA: Jossey-Bass.

Mills, J., Ayre, M., \& Gill, J. (2010). Gender Inclusive Engineering Education. London: Taylor and Francis.

Moore, W. (1970). The Professions: Roles and Rules: Roles and Rules. New York: Russell Sage Foundation.

Morsing, M., \& Schultz, M. (2006). Corporate social responsibility communication: stakeholder information, response and involvement strategies. Business Ethics: A European Review, 15(4), 323-338. http://onlinelibrary.wiley.com/doi/10.1111/j.1467$\underline{8608.2006 .00460 . x / \text { full }}$ 
Johnson, A

A Theoretical Basis for Addressing Culture in Undergraduate Mining Education

National Academy of Engineering. (2005). Educating the engineer of 2020: Adapting

Engineering Education to the New Century. Washington, DC: National Academies Press.

Owen, J., \& Kemp, D. (2013). Social licence and mining: a critical perspective. Resources Policy, 38(1), 29-35. http://www.in-dev.org/docs/Owen_Kemp-Social-Licence-2012.pdf

Parkinson, A. (2009). The rationale for developing global competence. Online Journal for Global Engineering Education, 4(2), 2.

http://digitalcommons.uri.edu/cgi/viewcontent.cgi?article $=1018 \&$ context $=$ ojgee

Persson, S., Harnesk, D., \& Islar, M. (2017). What local people? Examining the Gállok mining conflict and the rights of the Sámi population in terms of justice and power. Geoforum, 86, 20-29. https://doi.org/10.1016/j.geoforum.2017.08.009

Reid, S. \& Ng, S. (1999). Language, power and intergroup relations. Journal of Social Issues 55(1), 119-139.

http://journals1.scholarsportal.info/pdf/00224537/v55i0001/119 1pair.xml

Riley, D. (2008). Engineering and social justice. Synthesis Lectures on Engineers, Technology, and Society, 3(1), 1-152. Accessed April 3, 2015 at http://www.trincoll.edu/Academics/centers/TIIS/Documents/DonnaRileyEngineeringandS ocialJustice.pdf

Russell, B. (2014). On Education. London: Routledge.

Spivak, G. (1993). Foundations and cultural studies, in H. Silverman (Ed.), Questioning Foundations: Truth, Subjectivity and Culture (pp. 153-175). New York: Routledge.

Stevens, R., O’Connor, K., Garrison, L., Jocuns, A. \& Amos, D. (2008). Becoming an engineer: Toward a three dimensional view of engineering learning. Journal of Engineering Education 97(3), 355-68. http://onlinelibrary.wiley.com/doi/10.1002/j.21689830.2008.tb00984.x/epdf

Ting-Toomey, S. (1982). Toward a theory of conflict and culture. Conference Paper presented at the Annual Meeting of the Speech Communication Association, Louisville, KY, November 4-7, 1982.

Tonso, K. (2006). Student engineers and engineer identity: Campus engineer identities as figured world. Cultural studies of science education, 1(2), 273-307. https://link.springer.com/article/10.1007/s11422-005-9009-2

Triandis, H. (2000). Culture and conflict. International Journal of Psychology, 35(2), 145-152. https://doi.org/10.1080/002075900399448

Trice, H. (1993). Occupational Subcultures in the Workplace (No. 26). Ithaca, NY: Cornell University Press.

Tufte, T., \& Mefalopulos, P. (2009). Participatory communication: A practical guide (No. 170). World Bank Publications. 
Johnson, A

A Theoretical Basis for Addressing Culture in Undergraduate Mining Education

http://siteresources.worldbank.org/EXTDEVCOMMENG/Resources/Participatorycommu nication.pdf

Walker, M. 2001. Engineering identities. British Journal of Sociology of Education 22 (1), 7589. http://link.springer.com/article/10.1007/s10734-012-9541-4\#/page-1

Waziyatawin, A. \& Yellow Bird, M. (2005). For Indigenous Eyes Only: A Decolonization Handbook. Santa Fe, NM: School of American Research Press.

Weick, K. \& Quinn, R. (1999). Organizational change and development. Annual Review of Psychology 50: 361-86.

http://www.annualreviews.org/doi/pdf/10.1146/annurev.psych.50.1.361

Wenger, E. (1999). Communities of practice: Learning, meaning, and identity. Cambridge: Cambridge University Press.

http://www.linqed.net/media/15868/COPCommunities_of_practiceDefinedEWenger.pdf

Wilensky, H. (1964). The professionalization of everyone? American Journal of Sociology, 70(2), 137-158. http://www.jstor.org/stable/pdf/2775206.pdf 